Original Research Article

\title{
Seasonal variation in phytoplankton density of Bhagirathi River at Uttarkashi (Uttarakhand) India
}

Bantwan, Babita

Department of Zoology, Govt. P.G. College, Nagnath Pokhari, Chamoli

Corresponding Author: babitabantwan85@gmail.com

A R T I C L E I N F O

Received: 18 August 2018 | Accepted: 22 September 2018 | Published Online: 31 December 2018

DOI: $10.31786 / 09756272.18 .9 .2 .211$

EOI: 10.11208/essence.18.9.2.211

Article is an Open Access Publication.

This work is licensed under Attribution-Non Commercial 4.0 International

(https://creativecommons.org/licenses/by/4.0/)

CThe Authors (2018). Publishing Rights @ MANU_ICMANU \& ESSENCE-IJERC.

\section{A B S T R A C T}

Phytoplanktonic study is very important because they act as primary producers, food for variety of aquatic organisms and an efficient bio-indicator for water quality. Large population of phytoplankton is thriving in this wetland which enhances its productivity. A Total of 36 phytoplanktonic genera were identified in the present study. Bacillariophyceae include 15 genera, chlorophyceae include 10 genera, myxophyceae include 7 genera and desmidiaceae include 4 genera. In River Bhagirathi the

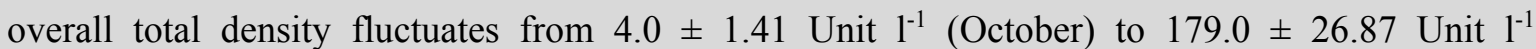
(November). Seasonal total density ranged from minimum $77.67 \pm 6.81$ Unit $^{-1}$ (monsoon) at site $\mathrm{S}_{1}$ to maximum $168.6 \pm 53.29$ Unit $^{-1}$ (winter) at site $\mathrm{S}_{2}$.

\section{K E Y W O R D S}

Phytoplanktons | Seasonal density | Diversity | River Bhagirathi

\section{I T A T I O N}

Bantwan, Babita (2018): Seasonal variation in phytoplankton density of Bhagirathi River at Uttarkashi (Uttarakhand) India. ESSENCE Int. J. Env. Rehab. Conserv. IX (1): 72-77. 


\section{Introduction}

Phytoplankton are minute, chlorophyll bearing organism, occupies the lowest level in aquatic food chain pyramid system. They form the base of a grazing food chain and work as primary producers by trapping solar energy in the aquatic ecosystems. These are the major source of dissolved oxygen in the water bodies and are a good indicator of water quality (Wetzel 1975, 2001; Lynch 1980; Pathani et al., 2002). Presence of plankton in any aquatic media directly affects the productivity of that aquatic system. Phytoplankton are very sensitive to changes in these environment and affects dissolved oxygen levels, nutrient concentrations, light levels, and zooplankton biomass. Plankton composition and diversity estimation have often been utilized to evaluate the overall health of riverine ecosystem.

\section{Materials and methods}

Two sampling sites $\left(\mathrm{S}_{1}\right.$ and $\left.\mathrm{S}_{2}\right)$ were selected on the river Bhagirathi. The sampling site $\mathrm{S}_{1}$ is after tailrace water meet with Original River at Joshiyara which is $16 \mathrm{~km}$. from Maneri and site $\mathrm{S}_{2}$ is before meeting point of tailrace water at Ujaly a distance from $14 \mathrm{~km}$. from Maneri. The Maneri dam is fifteen kilometer from the Uttarkashi district headquarter and about $165 \mathrm{Km}$. for from Rishikesh railway station. The Powerhouse of the dam is situated on right bank of river Bhagirathi in Tiloth, which is $1 \mathrm{Km}$. away from the district head quarter. The water of the Maneri Dam tunnel then again meets with the original river Bhagirathi at Tiloth. Phytoplankton samples were collected by filtering 100 liter of water through phytoplankton net of $20 \mu \mathrm{m}$ size and preserved using 4\% formalin. Phytoplankton was identified up to the lowest recognizable taxonomic unit mostly genus following keys by Needham and Needham (1962), Ward and Whipple (1959) and Sarode and Kamat (1984). Phytoplankton was enumerated using Sedgwick-Rafter Cell Counter and number of phytoplankton $\mathrm{ml}^{-1}$ of water was calculated according to Welch (1952).

\section{Results}

The four major groups of phytoplankton ware recorded viz. Bacillariophyceae, chlorophyceae, desmidiaceae and myxophyceae. A Total of 36 phytoplanktonic genera were identified in the present study. Bacillariophyceae include 15 genera, chlorophyceae include 10 genera, myxophyceae include 7 genera and desmidiaceae include 4 genera.

\begin{tabular}{|l|c|c|c|c|c|c|c|c|}
\hline \multirow{2}{*}{ Months } & \multicolumn{2}{|c|}{ Bacillariophyceae } & \multicolumn{2}{c|}{ Chlorophyceae } & \multicolumn{2}{c|}{ Desmidiaceae } & \multicolumn{2}{c|}{ Myxophyceae } \\
\cline { 2 - 9 } & $\mathbf{S}_{\mathbf{1}}$ & $\mathbf{S}_{\mathbf{2}}$ & $\mathbf{S}_{\mathbf{1}}$ & $\mathbf{S}_{\mathbf{2}}$ & $\mathbf{S}_{\mathbf{1}}$ & $\mathbf{S}_{\mathbf{2}}$ & $\mathbf{S}_{\mathbf{1}}$ & $\mathbf{S}_{\mathbf{2}}$ \\
\hline November & 82.05 & 77.34 & 4.69 & 8.59 & 5.64 & 7.81 & 6.15 & 6.25 \\
\hline December & 64.56 & 71.26 & 17.09 & 13.79 & 12.03 & 6.90 & 6.33 & 8.05 \\
\hline January & 58.93 & 64.8 & 17.86 & 15.20 & 16.96 & 14.4 & 6.25 & 5.60 \\
\hline February & 68.12 & 66.46 & 10.87 & 16.77 & 13.77 & 7.45 & 7.25 & 9.32 \\
\hline March & 72.91 & 69.23 & 11.33 & 12.31 & 8.37 & 9.23 & 7.39 & 9.23 \\
\hline April & 46.15 & 49.5 & 23.08 & 22.77 & 23.08 & 17.82 & 7.69 & 9.90 \\
\hline May & 45.24 & 53.44 & 27.38 & 20.61 & 17.86 & 16.79 & 9.52 & 9.16 \\
\hline June & 47.62 & 58.39 & 19.05 & 21.9 & 23.81 & 13.87 & 9.52 & 5.84 \\
\hline July & 50.00 & 51.61 & 18.75 & 21.51 & 25.0 & 16.13 & 6.25 & 10.75 \\
\hline August & 53.01 & 59.09 & 24.1 & 20.00 & 13.25 & 7.27 & 9.64 & 13.64 \\
\hline September & 42.86 & 49.06 & 34.29 & 26.42 & 8.57 & 9.43 & 14.29 & 15.09 \\
\hline October & 61.67 & 81.10 & 11.02 & 12.6 & 8.33 & 2.36 & 6.67 & 3.94 \\
\hline
\end{tabular}

Table1: Percentage fluctuation of Phytoplankton of River Bhagirathi during November 2007 to October 2008 
Bacillariophyceae (diatoms) contributed $41.67 \%$, chlorophyceae (green algae) contributed $27.78 \%$, desmidiaceae (desmids) contributed $11.11 \%$ and myxophyceae (blue green algae) contributed $19.44 \%$ of total population. The diversity of bacillariophyceae biomass was dominating the river Bhagirathi.The Bacillariophyceae had the maximum contribution $82.05 \%$ (November) at $\mathrm{S}_{1}$ to minimum $42.86 \%$ (September) at $\mathrm{S}_{1}$. The chlorophyceae contributes maximum of $34.29 \%$ (September) at $\mathrm{S}_{1}$ to minimum $4.69 \%$ (November) at $\mathrm{S} 1$. The desmidiaceae contributes maximum of $2.36 \%$ (October) at $\mathrm{S}_{2}$ to minimum $17.82 \%$ (April) at $\mathrm{S}_{2}$ and myxophyceae contributes maximum of $15.09 \%$ (September) at $\mathrm{S}_{2}$ to minimum 3.94\% (October) at $\mathrm{S}_{2}$ (Table 1)

\begin{tabular}{|l|c|c|c|c|}
\hline Months & Bacillariophyceae & Chlorophyceae & Desmidiaceae & Myxophyceae \\
\hline November & $179.0 \pm 26.87$ & $17.0 \pm 7.07$ & $15.5 \pm 6.36$ & $14.0 \pm 2.83$ \\
\hline December & $113.0 \pm 15.56$ & $25.5 \pm 2.12$ & $15.5 \pm 4.95$ & $12.0 \pm 2.83$ \\
\hline January & $73.5 \pm 10.61$ & $19.5 \pm 0.71$ & $18.5 \pm 0.71$ & $7.0 \pm 0.00$ \\
\hline February & $100.5 \pm 9.19$ & $21.0 \pm 8.49$ & $15.5 \pm 4.95$ & $12.5 \pm 13.54$ \\
\hline March & $119.0 \pm 41.01$ & $19.5 \pm 4.95$ & $14.5 \pm 3.54$ & $13.5 \pm 2.12$ \\
\hline April & $40.0 \pm 14.14$ & $19.0 \pm 5.66$ & $16.5 \pm 2.12$ & $7.5 \pm 3.54$ \\
\hline May & $54.0 \pm 22.63$ & $25.0 \pm 2.83$ & $18.5 \pm 4.95$ & $10.0 \pm 2.83$ \\
\hline June & $65.0 \pm 21.21$ & $25.0 \pm 7.07$ & $22.0 \pm 4.24$ & $9.0 \pm 1.41$ \\
\hline July & $44.0 \pm 5.66$ & $17.5 \pm 3.54$ & $17.5 \pm 3.54$ & $7.5 \pm 3.54$ \\
\hline August & $54.5 \pm 14.85$ & $21.0 \pm 1.41$ & $9.5 \pm 2.12$ & $11.5 \pm 4.95$ \\
\hline September & $41.0 \pm 15.56$ & $26.0 \pm 2.83$ & $8.0 \pm 2.83$ & $13.0 \pm 4.24$ \\
\hline October & $70.0 \pm 46.67$ & $15.0 \pm 1.41$ & $4.0 \pm 1.41$ & $4.5 \pm 0.71$ \\
\hline
\end{tabular}

Table 2: Class wise Mean \pm SE total density of Phytoplankton of River Bhagirathi during November 2007 to October 2008.

\begin{tabular}{|c|c|c|c|c|}
\hline Month & & Winter & Summer & Monsoon \\
\hline \multirow{2}{*}{ Bacillariophyceae } & S1 & $91.8 \pm 45.90$ & $66.6 \pm 54.95$ & $38.0 \pm 7.21$ \\
\cline { 2 - 5 } & S2 & $122.6 \pm 44.85$ & $72.5 \pm 17.08$ & $55.0 \pm 8.89$ \\
\hline \multirow{2}{*}{ Chlorophyceae } & S1 & $17.6 \pm 6.02$ & $20.25 \pm 3.77$ & $19.67 \pm 4.51$ \\
\cline { 2 - 5 } & S2 & $21.6 \pm 4.27$ & $24.0 \pm 6.06$ & $23.33 \pm 4.16$ \\
\hline \multirow{2}{*}{ Desmidiaceae } & S1 & $14.6 \pm 6.39$ & $18.0 \pm 4.76$ & $12.33 \pm 7.09$ \\
\cline { 2 - 5 } & S2 & $13.0 \pm 6.63$ & $17.75 \pm 4.19$ & $11.0 \pm 3.61$ \\
\hline \multirow{2}{*}{ Myxophyceae } & S1 & $8.6 \pm 3.13$ & $9.5 \pm 4.20$ & $7.67 \pm 2.52$ \\
\cline { 2 - 5 } & S2 & $11.4 \pm 5.03$ & $10.5 \pm 1.91$ & $13.67 \pm 3.21$ \\
\hline \multirow{2}{*}{ Total Density } & S1 & $132.6 \pm 50.65$ & $114.25 \pm 61.38$ & $77.67 \pm 6.81$ \\
\cline { 2 - 5 } & S2 & $168.6 \pm 53.29$ & $124.75 \pm 16.13$ & $103.0 \pm 8.89$ \\
\hline
\end{tabular}

Table 3: Seasonally Mean \pm SE of density of Phytoplankton in River Bhagirathi during November 2007 to October 2008. 
Quantitative fluctuation in the phytoplankton density of River Bhagirathi during the study period has been depicted in Table 2. In River Bhagirathi the overall total density fluctuates from $4.0 \pm 1.41$ Unit $^{-1}$ (October) to $179.0 \pm 26.87$ Unit $1^{-1}$ (November). The diatoms (bacillariophyceae) had the largest contribution followed by green algae (chlorophyceae), than followed by desmidiaceae (desmids) and myxophyceae. (Fig.1). The total density of bacillariophyceae ranged from $40.0 \pm 14.14$ Unit $^{1}{ }^{1}$ (April) to 179.0 \pm 26.87 Unit $^{-1}{ }^{-1}$ (November). The total density of chlorophyceae was minimum $15.0 \pm 1.41$ (October) to maximum $26.0 \pm 2.93$ (September). The total density of desmidiaceae ranged from 4.0

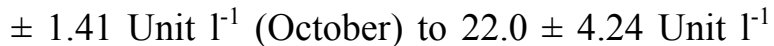
(June). The total density of myxophyceae varied from $4.5 \pm 0.71$ Unit $^{-1}$ (October) to $14.0 \pm 2.83$ (November). Seasonal density of bacillariophyceae ranged from minimum $38.0 \pm$ 7.21 Unit $\mathrm{l}^{-1}$ (monsoon) at site $\mathrm{S}_{1}$ to maximum $122.6 \pm 44.85$ Unit $^{-1}{ }^{-1}$ (winter) at site $S_{2}$. Seasonal density of chlorophyceae ranged from minimum $19.67 \pm 4.51$ Unit $1^{-1}$ (monsoon) at site $\mathrm{S}_{1}$ to maximum $24.0 \pm 0.06$ Unit $^{-1}$ (summer) at site $S_{2}$. Seasonal density of desmidiaceae ranged from minimum $11.0 \pm 3.61$ Unit $^{-1}$ (monsoon) at site $\mathrm{S}_{2}$ to maximum $18.0 \pm 4.76$ Unit $^{-1}$ (summer) at site $\mathrm{S}_{1}$.

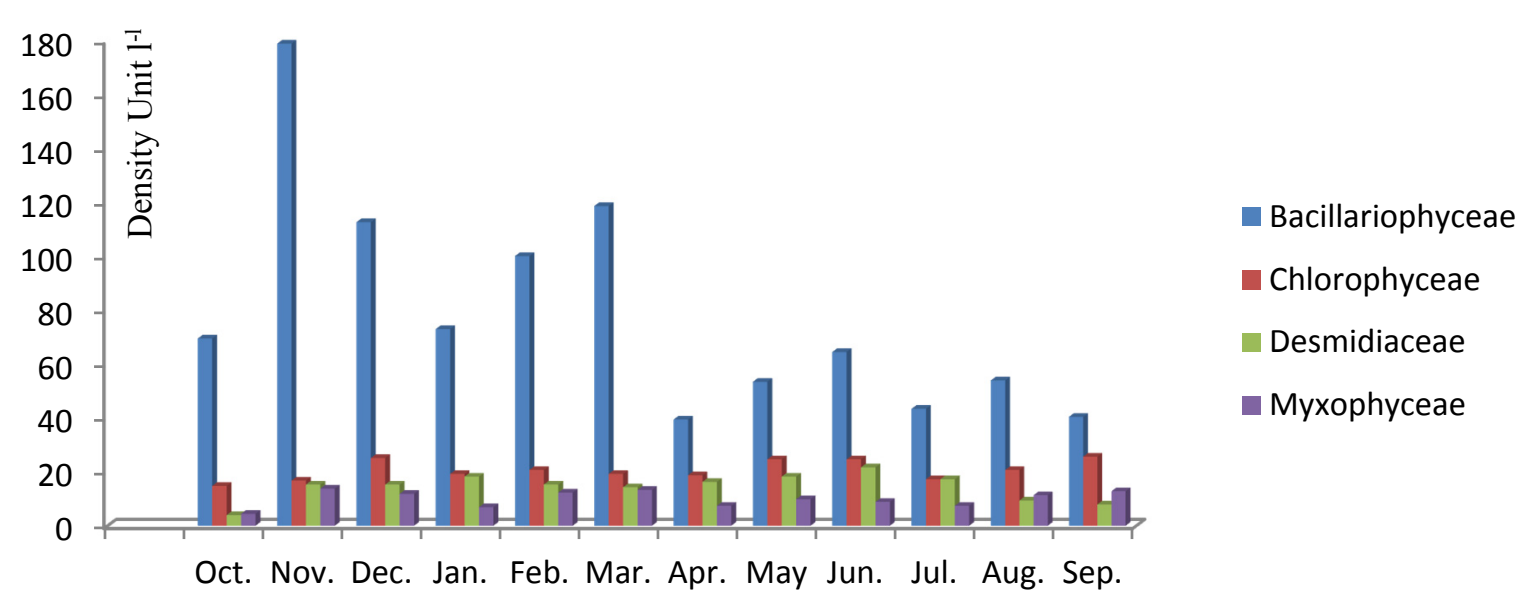

Fig. 1: Graph showing fluctuation in total density of phytoplankton during November 2007-October

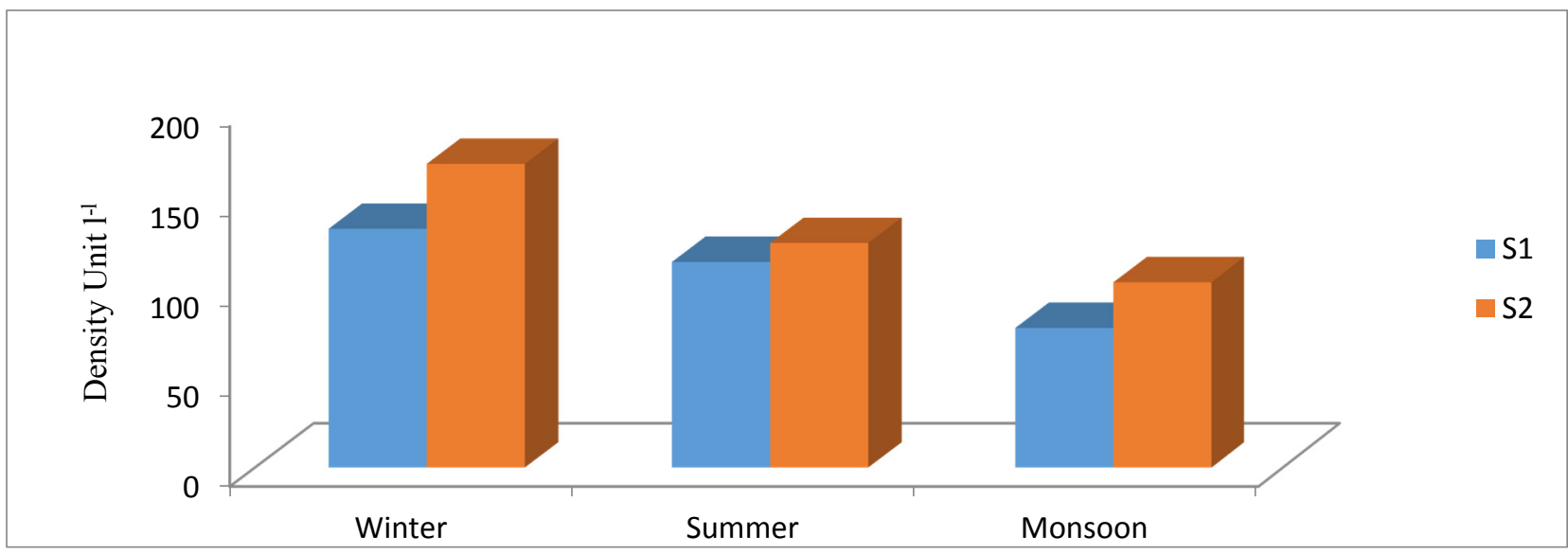

Fig. 2: Graph showing fluctuation in seasonal density of phytoplankton during November 2007October, 2008. 
Seasonal density myxophyceae ranged from minimum $7.67 \pm 2.52$ Unit $^{-1}$ (monsoon) at site $\mathrm{S}_{1}$ to maximum $11.4 \pm 5.03$ Unit $1^{-1}$ (winter) at site $\mathrm{S}_{2}$. Total density ranged from minimum $77.67 \pm$ 6.81 Unit $1^{-1}$ (monsoon) at site $S_{1}$ to maximum $168.6 \pm 53.29$ Unit $^{-1}$ (winter) at site $\mathrm{S}_{2}$ (Table 3 $\&$ Figure 2).

\section{Discussion}

During the study on phytoplankton production in the snow-fed river Bhagirathi in the Garhwal Himalaya. Joshi et al. (1996b) observed planktonic density of Ganga canal at Jawalapur (Haridwar) and reported that the plankton density was maximum during winter and it decreased due to increased turbidity during rainy season. Joshi et al. (1996a) studied selected tributaries of river Ganga and recorded highest population of plankton during winter season with maximum plankton recorded from December to February and lowest population during monsoon months. Datta and Banik (1997) concluded that during monsoon, growth of periphyton (mainly constituted by the green and blue green algae and diatoms) was less, which was due to change in physico-chemical environment in the eco-system and also due to the effect of water flow, turbulence and increased depth of water. Agarwal and Thapliyal (2005) carried out hydrobiological studied on Bhilangana river and concluded that the maxima fauna density in winter and minima in monsoon season may be due to water temperature, water velocity, and turbidity been lower in winter months and these provide favourable environment for the growth of plankton and other biotic communities. Similar observations were made during the present investigation. Farzaneh et al. (2006) have studied the phytoplankton diversity and nutrients at the Jajerood River in Iran and recorded a total of 53 taxa, belonging to four algae classes: Bacillariophyceae, chlorophyceae, cyanophyceae, and dinophyceae. Bacillariophyceae appeared to be dominant group in terms of total genus number during the study period. They also stated that number of phytoplankton genus was high in summer and quite low in winter. In the present study maximum number of phytoplankton was reported during the winter months whereas maximum density of phytoplankton genus was reported as bacillariophyceae.

\section{References}

Agarwal, N. K. and Thapliyal, B.L. (2005): Preimpoundment hydrological study of Bhilangana River from Tehri Dam reservoir area in Uttaranchal. Environ. Geochem. 8: 143-148.

Datta, N. C. and Banik, S. (1997): Structure and seasonal abundance of the periphytic community of a freshwater lake in Calcutta. Environ. Ecol. 5: 501-504.

Farzaneh, F., Korehi, H., Mollakarami, S., Skandari, S., Zaferani, S. G. G, and Shashm, Z. M. C. (2006): Phytoplankton diversity and nutrients at the Jajerood river in Iran. Pakistan J. Biological Science. 9(9): 1787-1790.

Joshi, B. D., Bisht, R. C. S. and Joshi, N. (1996a): Planktonic population in relation to certain physico-chemical feators of Ganga canal at Jawalapur (Hardwar). Him. J. Environ. Zool. 10: 75-77.

Joshi, B. D., Bisht, R. C. S., Joshi, N. and Singh, R. (1996b): A study of planktonic and benthic components of three selected tributaries of River Ganga between Devprayag and Rishikesh. Him. J. Environ. Zool. 10: 23-26.

Lynch, M. (1980): The evolution of cladoceran life histories. Q. Rev. Biol. 55: 23-42.

Needham, J. G. and Needham, P. R. (1962): A Guide to the study of freshwater biology, Holdan Day Inc. San. Francisio.

Pathani S. S., Upadhyay K. K. and Joshi S. K. (2002): Some physico-chemical parameters and primary productivity of river 
West Ramganga (Uttaranchal). Him. J. Env. Zool. 16(2): 151- 158.

Sarode, P. T. and Kamat, N. D. (1984): Freshwater Diatoms of Maharashtra. Saikripa Prakashan Aurangabad.

Matta, G. (2014): "A study on physico-chemical Characteristics to assess the pollution status of river Ganga in Uttarakhand." Journal of Chemical and Pharmaceutical Sciences, 7(3): 210-217.

Matta, G. and Kumar, A. (2015): Monitoring and Evaluation of River Ganga System in Himalayan Region with Reference to Limnological Aspects. World Applied Sciences Journal, 33 (2): 203-212.

Matta, G. and Kumar, A. (2017): Health Risk, Water Hygiene, Science and Communication. ESSENCE Int. J. Env. Conser. Rehab, 8(1): 179 - 186.

Matta, G. and Laura, G. (2016): Mercury, lead and arsenic: impact on environment and human health India. Journal of Chemical and Pharmaceutical Sciences, 9(2): 718 - 725.

Matta, G.; Bhadauriya, G. and Singh, V. (2011): Biodiversity and Sustainable Development: A Review. ESSENCE - Int J for Env Rehab and Conser, 2(1): $72-80$.

Matta, G.; Laura, G.; Kumar, A. and Machel, J. (2018): Hydrochemical characteristics and planktonic composition assessment of River Henwal in Himalayan Region of Uttarakhand using CPI, Simpson's and Shannon-Weaver Index. Journal of Chemical and Pharmaceutical Sciences, 11(1).

Ward, H. B. and Whipple, G. G. (1966): Freshwater Biology (Eds.) W.T. Edmondson, John. Willy \& Sons, Inc. New York.

Welch, P. S. (1952): Limnological Methods, XVIII Macgrow Hill Brok Co. Inc. New York.
Wetzel, R. G. (1975): Limnology. W.B. Saunders Company, Philadelphia, USA, 743 pp. 14.

Wetzel, R. G. (2001): Limnology: Lake and River Ecosystems, Academic Press, San Diego. 1006. 
ESSENCE—IJERC | Bantwan (2018) | IX (2): 72—77 